\title{
WEED INFESTATION OF A SPRING WHEAT (Triticum aestivum L.) CROP UNDER THE CONDITIONS OF PLOUGH AND PLOUGHLESS TILLAGE
}

\author{
Andrzej Woźniak \\ University of Life Sciences in Lublin, Department of Herbology and Plant Cultivation Techniques \\ 20-950 Lublin, Akademicka 13, Poland, e-mail: andrzej.wozniak@up.lublin.pl
}

Received: 12.04.2011

\begin{abstract}
A field experiment was conducted in the period 20072009 in the Uhrusk Experimental Farm (Lublin region) belonging to the University of Life Sciences in Lublin. Different tillage systems - plough and ploughless tillage - were the experimental factors. In the plough tillage system, tillage involved skimming done after the harvest of the forecrop and autumn ploughing. In the ploughless tillage system, only the herbicide Roundup 360 SL (active substance - glyphosate) was applied after the harvest of the forecrop. In both tillage treatments, spring tillage involved field cultivating and the use of a tillage assembly consisting of a cultivator, cage roller, and harrow. The present experiment evaluated weed infestation of the crop expressed by the number and air-dry weight of weeds and their species composition. Under the conditions of ploughless tillage, air-dry weight of weeds in the spring wheat crop was shown to increase significantly compared to plough tillage. The tillage systems under comparison did not differentiate the number of weeds per $1 \mathrm{~m}^{2}$. Spring wheat sown using plough tillage was colonized most extensively by the following weed species: Avena fatua L., Stellaria media (L.) Vill., Galium aparine L., Amaranthus retroflexus L., Chenopodium album L., and Consolida regalis Gray. In the ploughless tillage treatments, the following weeds were predominant: Stellaria media (L.) Vill., Avena fatua L., Fallopia convolvulus (L.) A. Löve, Papaver rhoeas L., Amaranthus retroflexus L., Galium aparine L., and Chenopodium album L.
\end{abstract}

Key words: spring wheat, plough tillage, ploughless tillage, number of weeds, air-dry weight of weeds, species composition

\section{INTRODUCTION}

The weed infestation level in cereal crops is affected by many factors, among which the most important role is attributed to the soil diaspore bank, agricultural practices used, and habitat conditions ( $\mathrm{K} \mathrm{r}$ a s k a and Pałys, 2006; Sekutowski and Rola, 2006). The literature of the subject shows that fruits and seeds in the soil are a potential source of crop weed infestation, which is reflected in weed infestation of the crop (Wes ołowski and Woźniak, 2001; Feledyn-Szewczyk and Duer, 2007). The weed infestation level is also dependent on the tillage system. Weber and Hryńczuk (2005) showed that reduced tillage increased weed infestation of a winter wheat crop compared to conventional tillage and direct drilling or sowing. Similar conclusions were also made by Gaw ę d a (2007). She showed an increase in the weed infestation rates under the conditions of ploughless tillage compared to plough tillage. In the study of W oźn i a k (2010), ploughless tillage also had an effect on the increase in the number and weight of weeds in comparison with plough tillage. In turn, plough tillage promoted the increase in the number of weed species compared to ploughless tillage. Sekutowski and Rola (2006) draw attention to the increase in the number of fruits and seeds in the soil under the conditions of ploughless tillage, whereas Dzienia and Dojss (1999) to their distribution in the soil. As shown by research, in ploughless tillage systems diaspores accumulate primarily in the topsoil, hence when they germinate they affect weed infestation of the crop plant.

The aim of the present study was to compare the values of the weed infestation parameters (number of weeds per $1 \mathrm{~m}^{2}$, air-dry weight of weeds in $\mathrm{g} \mathrm{x} \mathrm{m}^{-2}$, and species composition) in a spring wheat crop sown using plough and ploughless tillage systems.

\section{MATERIALS AND METHODS}

A field experiment was conducted in the period 2007-2009 in the Uhrusk Experimental Farm (Lublin 
region) belonging to the University of Life Sciences in Lublin. It was set up on mixed rendzina soil with the composition of light, slightly sandy loam and was carried out in 3 replicates on $24 \mathrm{~m}^{2}$ plots. The experiment evaluated weed infestation of a crop of spring wheat Triticum aestivum L. sown using plough and ploughless tillage systems. Plough tillage involved skimming (harrowed) done after the harvest of the forecrop (pea) and autumn ploughing. Ploughless tillage was limited to a single application of the herbicide Roundup 360 SL (active substance - glyphosate) - $41 \mathrm{x} \mathrm{ha}^{-1}$ as a post-harvest treatment. In both tillage treatments, spring tillage involved field cultivating and the use of a tillage assembly consisting of a cultivator, cage roller, and harrow. Weed control in the wheat crop under both tillage systems was reduced to harrowing the crop once at the tillering stage.

Weed infestation of the crop was assessed using the botanical gravimetric method. This method consists in the determination of the species composition of weeds as well as their number and air-dry weight per $1 \mathrm{~m}^{2}$ of the plot. This sampling area was randomly selected (twice) using a frame with the dimensions of $1 \mathrm{~m} \times 0.5 \mathrm{~m}$. The determination of air-dry weight of weeds consists in collecting all weeds from within the frame, removing their root systems and placing the weeds in a well-aired and dry place until the time when a constant weight is obtained. In the present study, the number and air-dry weight of weeds as well as weed species composition were determined at the dough stage of maturity of the wheat crop.

\section{RESULTS}

The growing seasons in which the present study was conducted differed significantly in terms of total rainfall (Table 1). During the period from sowing of spring wheat to its harvest, i.e. from April to August, the rainfall level was by far the highest in 2007 (467.4 $\mathrm{mm})$, total rainfall was lower in $2009(380.5 \mathrm{~mm})$, while it was the lowest in 2008 (312.7 mm). It can be presumed that these conditions affected the weed infestation parameters, in particular the number of weeds and their air-dry weight. The data contained in Table 2 show that the highest amount of weeds (on average 137.9 per $1 \mathrm{~m}^{2}$ ) occurred in 2007 , i.e. the year with the highest total rainfall, this number was lower in 2009 $\left(80.8\right.$ per $\left.1 \mathrm{~m}^{2}\right)$, and the lowest $\left(51.5\right.$ per $\left.1 \mathrm{~m}^{2}\right)$ in the year 2008 with the lowest rainfall level. High rainfall increased the number of weeds per $1 \mathrm{~m}^{2}$, in particular under the conditions of plough tillage. In turn, when analysing the number of weeds, irrespective of the study year, one can see that the tillage system (plough or ploughless tillage) did not affect the value of this parameter. The relations between the values for air-dry weight of weeds were similar to those relating to the above-mentioned trait (Table 3). The weeds produced a significantly lower weight in 2008 than in the other years. Relative to the year 2007, it was lower by $67.4 \%$, whereas compared to 2009 by more than $53 \%$. The tillage system also modified the trait under study. The weight produced by weeds in the ploughless tillage treatments was more than $31 \%$ higher than that in the ploughed plots. Air-dry weight of weeds was also impacted by the interaction of the study years and tillage system. In the ploughless tillage treatments, weeds produced the lowest weight in $2008\left(30 \mathrm{~g} \mathrm{x} \mathrm{m}^{-2}\right)$, and the highest one in $2007\left(92.2 \mathrm{~g} \mathrm{x} \mathrm{m}^{-2}\right)$.

The tillage systems under evaluation also affected weed species composition. In 2007 the plough tillage treatments were colonized by 30 species, including 27 annual species and 3 perennial ones (Table 4). Among the annual species, the following were found: Avena fatua L., Consolida regalis Gray, Stellaria media (L.) Vill., Chenopodium album L., Galeopsis tetrahit L., and Galium aparine L. Perennial weeds were represented by Cirsium arvense (L.) Scop., Convolvulus arvensis L., and Elymus repens (L.) P.B. In 2008 the presence of 26 species was found - 24 annual species and 2 perennial ones. Among the annual species, the following had the highest numbers: Stellaria media L., Chenopodium album L., Avena fatua L., Galium aparine L., Papaver rhoeas L., and Galinsoga parviflora Cav., whereas in the group of perennials, these were Cirsium arvense (L.) Scop. and Convolvulus arvensis L. In 2009 the wheat crop was colonized by 19 weed species - 18 annual species and 1 perennial species. Among the short-lived species, the following were predominant in quantitative terms: Avena fatua L., Amaranthus retroflexus L., Papaver rhoeas L., Galinsoga parviflora Cav., Galium aparine L., and Melandrium album (Mill.) Garcke, while in the group of perennials it was Cirsium arvense (L.) Scop.

Under the conditions of ploughless tillage, in 2007 the weed community was composed of 28 species, including 24 annual species and 4 perennial ones (Table 5). The following occurred most frequently: Stellaria media (L.) Vill., Avena fatua L., Echinochloa crus-galli (L.) P.B., Chenopodium album L., Galium aparine L., and Consolida regalis Gray. Perennial species were represented in the greatest number by the following weeds: Cirsium arvense (L.) Scop., Convolvulus arvensis L., Elymus repens (L.) P.B., and Sonchus arvensis L. In 2008 the wheat crop was colonized by 25 weed species -21 annual species and 4 perennial ones. The following short-lived species were the most numerous: Stellaria media (L.) Vill., Chenopodium album L., Galium aparine L., Avena fatua L., Papaver rhoeas L., and Polygonum aviculare L. Perennial weeds were represented by the following: Cirsium arvense (L.) Scop., Convolvulus arvensis L., Elymus repens (L.) P.B., and Sonchus arvensis L. In the last 
year of the study (2009), the presence of 23 species 19 annual species and 4 perennial ones - was found in the wheat crop. The following annual weeds occurred in the greatest number: Amaranthus retroflexus L., Papaver rhoeas L., Avena fatua L., Fallopia convolvulus (L.) A. Löve, and Galium aparine L. Perennial species were as follows: Cirsium arvense (L.) Scop., Sonchus arvensis L., Convolvulus arvensis L., and Elymus repens (L.) P.B.

In analysing the spatial distribution of weeds in the wheat crop, it was found that species belonging to the middle layer made up a large majority, $40 \%$ in total, weed species in the upper and lower layers accounted for $22.9 \%$ in each layer, whereas weeds in the ground layer constituted $14.2 \%$ (Table 6). Differences in weed species composition were found with respect to the tillage systems under comparison, in particular in the middle and lower layers. The following weed species were not found in the plough tillage treatments: Atriplex patula L., Raphanus raphanistrum L., Vicia villosa Roth., Erodium cicutarium (L.) L'Herit, and Galinsoga parviflora Cav. It can be presumed that diaspores of these weeds were located in the deeper soil layers (where they got together with animal manure), and they were moved to the soil surface during ploughing.

Table 1.

Total rainfall in 2007-2009 in the Uhrusk Experimental Farm

\begin{tabular}{|c|c|c|c|c|}
\hline \multirow{2}{*}{ Months } & \multicolumn{3}{|c|}{ Years } & \multirow{2}{*}{$\begin{array}{l}\text { Long-term data } \\
\text { (1989-2006) }\end{array}$} \\
\hline & 2007 & 2008 & 2009 & \\
\hline IV & 24.4 & 50.0 & 27.0 & 48.0 \\
\hline V & 98.8 & 69.0 & 81.5 & 58.6 \\
\hline VI & 96.0 & 37.7 & 169.3 & 65.6 \\
\hline VII & 156.8 & 117.0 & 42.7 & 83.9 \\
\hline VIII & 91.4 & 39.0 & 60.0 & 75.6 \\
\hline Total & 467.4 & 312.7 & 380.5 & 331.6 \\
\hline
\end{tabular}

Table 2 .

Number of weeds per $1 \mathrm{~m}^{2}$ in the spring wheat crop

\begin{tabular}{cccc}
\hline Years & Plough tillage & Ploughless tillage & Mean \\
\hline 2007 & 174.2 & 101.5 & 137.9 \\
2008 & 38.5 & 64.5 & 51.5 \\
2009 & 52.7 & 108.8 & 80.8 \\
\hline Mean & $\mathbf{8 8 . 5}$ & $\mathbf{9 1 . 6}$ & - \\
\hline
\end{tabular}

$\operatorname{LSD}(\mathrm{p}=0.05)$

Between years -24.5

Between tillage systems - n.s.

Years x tillage systems -39.5

Table 3.

Air-dry weight of weeds in $\mathrm{g} \mathrm{x} \mathrm{m}^{-2}$ in the spring wheat crop

\begin{tabular}{cccc}
\hline Years & Plough tillage & Ploughless tillage & Mean \\
\hline 2007 & 98.0 & 86.3 & 92.2 \\
2008 & 19.9 & 40.1 & 30.0 \\
2009 & 34.0 & 93.8 & 63.9 \\
\hline Mean & $\mathbf{5 0 . 6}$ & $\mathbf{7 3 . 4}$ & - \\
\hline
\end{tabular}

$\operatorname{LSD}(\mathrm{p}=0.05)$

Between years -19.7

Between tillage systems -16.2

Years x tillage systems -30.1 
Table 4.

Species composition and number of weeds per $1 \mathrm{~m}^{2}$ in the spring wheat crop under the conditions of plough tillage

\begin{tabular}{|c|c|c|c|c|}
\hline \multirow{2}{*}{ Species composition } & \multicolumn{3}{|c|}{ Years } & \multirow{2}{*}{ Mean } \\
\hline & 2007 & 2008 & 2009 & \\
\hline \multicolumn{5}{|l|}{ I. Annual } \\
\hline 1. Avena fatua $\mathrm{L}$. & 21.0 & 4.0 & 12.0 & 12.3 \\
\hline 2. Consolida regalis Gray & 19.0 & 1.0 & - & 6.7 \\
\hline 3. $\quad$ Stellaria media (L.) Vill. & 16.0 & 5.5 & 1.0 & 10.5 \\
\hline 4. Chenopodium album $\mathrm{L}$. & 15.5 & 4.5 & - & 6.7 \\
\hline 5. Galeopsis tetrahit $\mathrm{L}$. & 15.0 & 0.8 & 1.5 & 5.8 \\
\hline 6. Galium aparine L. & 15.0 & 3.5 & 4.0 & 7.5 \\
\hline 7. Capsella bursa-pastoris (L.) Med. & 10.5 & 0.5 & - & 3.7 \\
\hline 8. Papaver rhoeas $\mathrm{L}$. & 10.5 & 2.5 & 6.0 & 6.3 \\
\hline 9. Thlaspi arvense $\mathrm{L}$. & 10.5 & 0.5 & - & 3.7 \\
\hline 10. Fallopia convolvulus (L.) A. Löve & 6.5 & 0.8 & 1.0 & 5.8 \\
\hline 11. Polygonum aviculare $\mathrm{L}$. & 6.5 & 1.5 & 0.5 & 2.8 \\
\hline 12. Raphanus raphanistrum $\mathrm{L}$. & 2.5 & 1.9 & 1.5 & 2.0 \\
\hline 13. Apera spica-venti (L.) P.B. & 2.2 & - & 0.2 & 0.8 \\
\hline 14. Galinsoga parviflora Cav. & 2.2 & 2.5 & 5.0 & 3.2 \\
\hline 15. Melandrium album (Mill.) Garcke & 1.8 & 0.5 & 2.0 & 1.4 \\
\hline 16. Euphorbia helioscopia L. & 1.5 & - & - & 0.5 \\
\hline 17. Sonchus oleraceus L. & 1.5 & 0.5 & - & 0.7 \\
\hline 18. Lamium amplexicaule $\mathrm{L}$. & 1.2 & - & - & 0.4 \\
\hline 19. Amaranthus retroflexus L. & 1.0 & 1.2 & 12.0 & 7.7 \\
\hline 20. Poa annua $\mathrm{L}$. & 1.0 & 1.8 & 0.5 & 4.1 \\
\hline 21. Anthemis arvensis L. & 0.8 & 0.5 & - & 0.4 \\
\hline 22. Viola arvensis Murr. & 0.8 & 0.8 & - & 0.5 \\
\hline 23. Sonchus asper (L.) Hill. & 0.5 & 0.2 & 1.2 & 0.6 \\
\hline 24. Anagallis arvensis L. & 0.2 & 0.2 & 0.2 & 0.2 \\
\hline 25. Atriplex patula $\mathrm{L}$. & 0.2 & 0.2 & 0.8 & 0.4 \\
\hline 26. Erodium cicutarium (L.) L'Herit & 0.2 & - & 0.2 & 0.1 \\
\hline 27. Fumaria officinalis L. & 0.2 & 0.2 & - & 0.1 \\
\hline 28. Vicia villosa Roth. & - & 0.5 & 1.3 & 0.6 \\
\hline Number of annual weeds (I) & 163.8 & 36.1 & 50.9 & 95.5 \\
\hline \multicolumn{5}{|l|}{ II. $\quad$ Perennial } \\
\hline 29. Cirsium arvense (L.) Scop. & 5.4 & 2.2 & 1.8 & 3.1 \\
\hline 30. Convolvulus arvensis L. & 3.0 & 0.2 & - & 1.1 \\
\hline 31. Elymus repens (L.) P.B. & 2.0 & - & - & 0.7 \\
\hline Number of perennial weeds (II) & 10.4 & 2.4 & 1.8 & 4.9 \\
\hline Total I + II & 174.2 & 38.5 & 52.7 & - \\
\hline Number of species & 30 & 26 & 19 & $31^{\mathrm{x}}$ \\
\hline
\end{tabular}

$\mathrm{x}$ number of species over the 3 -year period 
Table 5.

Species composition and number of weeds per $1 \mathrm{~m}^{2}$ in the spring wheat crop under the conditions of ploughless tillage

\begin{tabular}{|c|c|c|c|c|}
\hline \multirow{2}{*}{ Species composition } & \multicolumn{3}{|c|}{ Years } & \multirow{2}{*}{ Mean } \\
\hline & 2007 & 2008 & 2009 & \\
\hline \multicolumn{5}{|l|}{ I. Annual } \\
\hline 1. Stellaria media ( L.) Vill. & 21.5 & 16.3 & 2.0 & 19.3 \\
\hline 2. Avena fatua $\mathrm{L}$. & 19.0 & 6.5 & 16.8 & 14.1 \\
\hline 3. Echinochloa crus-galli (L.) P.B. & 12.5 & - & 0.8 & 4.4 \\
\hline 4. Chenopodium album $\mathrm{L}$. & 12.4 & 11.5 & - & 8.0 \\
\hline 5. Galium aparine $\mathrm{L}$. & 5.5 & 11.1 & 8.0 & 8.2 \\
\hline 6. Consolida regalis Gray & 4.5 & - & 0.2 & 1.6 \\
\hline 7. Papaver rhoeas L. & 3.5 & 4.3 & 18.5 & 8.8 \\
\hline 8. Galeopsis tetrahit L. & 2.5 & 0.9 & 3.2 & 2.2 \\
\hline 9. Melandrium album (Mill.) Garcke & 2.5 & 1.1 & 3.0 & 2.2 \\
\hline 10. Polygonum aviculare L. & 2.5 & 3.4 & - & 2.0 \\
\hline 11. Anthemis arvensis L. & 2.2 & 0.1 & - & 0.8 \\
\hline 12. Capsella bursa-pastoris (L.) Med. & 2.2 & 1.4 & - & 1.2 \\
\hline 13. Amaranthus retroflexus L. & 1.5 & 1.5 & 22.5 & 8.5 \\
\hline 14. Poa апnua $\mathrm{L}$. & 1.5 & 1.4 & - & 1.0 \\
\hline 15. Fallopia convolvulus (L.) A. Löve & 1.0 & 1.6 & 16.8 & 9.5 \\
\hline 16. Sonchus oleraceus L. & 1.0 & 0.1 & 2.2 & 1.1 \\
\hline 17. Anagallis arvensis L. & 0.8 & 0.1 & 1.8 & 0.9 \\
\hline 18. Apera spica-venti (L.) P.B. & 0.8 & 0.5 & 1.5 & 0.9 \\
\hline 19. Lapsana communis L. & 0.8 & - & 1.2 & 0.7 \\
\hline 20. Viola arvensis Murr. & 0.8 & 0.4 & - & 0.4 \\
\hline 21. Sonchus asper (L.) Hill. & 0.5 & 0.1 & 4.0 & 1.5 \\
\hline 22. Veronica persica Poir. & 0.5 & - & 0.2 & 0.2 \\
\hline 23. Lamium amplexicaule L. & 0.2 & - & 0.5 & 0.2 \\
\hline 24. Thlaspi arvense $\mathrm{L}$. & 0.2 & 1.0 & - & 0.4 \\
\hline 25. Fumaria officinalis $\mathrm{L}$ & - & 0.2 & 0.8 & 0.3 \\
\hline 26. Euphorbia helioscopia L. & - & 0.2 & 0.5 & 0.2 \\
\hline Number of annual weeds (I) & 100.4 & 63.7 & 104.5 & 98.6 \\
\hline \multicolumn{5}{|l|}{ II. Perennial } \\
\hline 27. Cirsium arvense (L.) Scop. & 0.5 & 0.2 & 1.8 & 0.8 \\
\hline 28. Convolvulus arvensis L. & 0.2 & 0.2 & 0.5 & 0.3 \\
\hline 29. Elymus repens (L.) P.B. & 0.2 & 0.2 & 0.2 & 0.2 \\
\hline 30. Sonchus arvensis L. & 0.2 & 0.2 & 1.8 & 0.7 \\
\hline Number of perennial weeds (II) & 1.1 & 0.8 & 4.3 & 2.0 \\
\hline Total I + II & 101.5 & 64.5 & 108.8 & - \\
\hline Number of species & 28 & 25 & 23 & $30^{x}$ \\
\hline
\end{tabular}

$\mathrm{x}$ number of species over the 3-year period 
Table 6.

Spatial distribution of weeds in the spring wheat crop

Species composition

Weed layer in the crop

Plough tillage

Ploughless tillage

\begin{tabular}{|c|c|c|}
\hline I. Upper layer & & \\
\hline 1. Apera spica-venti (L.) P.B. & + & + \\
\hline 2. Avena fatua $\mathrm{L}$. & + & + \\
\hline 3. Consolida regalis Gray & + & + \\
\hline 4. Cirsium arvense (L.) Scop. & + & + \\
\hline 5. Papaver rhoeas L. & + & + \\
\hline 6. Sonchus arvensis L. & - & + \\
\hline 7. Sonchus asper (L.) Hill & + & + \\
\hline 8. Sonchus oleraceus L. & + & + \\
\hline \multicolumn{3}{|l|}{ II. Middle layer } \\
\hline 9. Elymus repens (L.) P. B. & + & + \\
\hline 10. Amaranthus retroflexus L. & + & + \\
\hline 11. Anthemis arvensis $\mathrm{L}$. & + & + \\
\hline 12. Atriplex patula $\mathrm{L}$. & + & - \\
\hline 13. Chenopodium album $\mathrm{L}$. & + & + \\
\hline 14. Convolvulus arvensis L. & + & + \\
\hline 15. Echinochloa crus-galli (L.) P.B. & - & + \\
\hline 16. Fallopia convolvulus (L.) A. Löve & + & + \\
\hline 17. Galeopsis tetrahit $\mathrm{L}$ & + & + \\
\hline 18. Galium aparine $\mathrm{L}$. & + & + \\
\hline 19. Lapsana communis L. & - & + \\
\hline 20. Melandrium album (Mill.) Garcke & + & + \\
\hline 21. Raphanus raphanistrum $\mathrm{L}$. & + & - \\
\hline 22. Vicia villosa Roth. & + & - \\
\hline \multicolumn{3}{|l|}{ III. Lower layer } \\
\hline 23. Capsella bursa-pastoris (L.) Med. & + & + \\
\hline 24. Euphorbia helioscopia L. & + & + \\
\hline 25. Erodium cicutarium (L.) L'Herit & + & - \\
\hline 26. Fumaria officinalis L. & + & + \\
\hline 27. Galinsoga parviflora Cav. & + & - \\
\hline 28. Lamium amplexicaule $\mathrm{L}$. & + & + \\
\hline 29. Thlaspi arvense L. & + & + \\
\hline 30. Viola arvensis Murr. & + & + \\
\hline \multicolumn{3}{|l|}{ IV. Ground layer } \\
\hline 31. Anagallis arvensis L. & + & + \\
\hline 32. Poa annua $\mathrm{L}$. & + & + \\
\hline 33. Polygonum aviculare L. & + & + \\
\hline 34. Veronica persica Poir. & - & + \\
\hline 35. Stellaria media (L.) Vill. & + & + \\
\hline
\end{tabular}




\section{DISCUSSION}

The literature on weed infestation of cereal plants is very wide and clearly shows significant relationships between crop weed infestation, soil diaspore bank, agricultural practices used, and habitat conditions ( $\mathrm{Fe} \mathrm{le}$ dyn-Szewczyk and Duer, 2007; Sekutowski and Rola, 2006; Wesołowski and Woźniak, 2001; Wrzesińska et al. 2003). An earlier study of W o źn i a k (2007), carried out under the same soil and habitat conditions, can complement the present study. It shows a great similarity between the soil seed bank and weed infestation of the crop. In the above cited study, the following weed species occurred in the greatest number: Chenopodium album L., Amaranthus retroflexus L., Stellaria media (L.) Vill., Galium aparine L., Viola arvensis Murr., and Avena fatua $\mathrm{L}$.

It can be concluded on the basis of the present study that the tillage system (plough or ploughless tillage) slightly differentiated the number and species composition of weeds, but it significantly affected their air-dry weight. Weather conditions influenced the weed infestation measures to a much greater degree. High rainfall levels had an effect on the increase in the number and air-dry weight of weeds in both tillage systems, as compared to the seasons with lower rainfall levels. Moist soil and appropriately high temperature promote the emergence of weeds, hence their presence is then much higher than in the years with lower rainfall.

The studies of Dzienia and Dojss (1999) as well as of Wrzesińska et al. (2003) show that the variation in weed infestation between the plough and ploughless tillage systems is a result of different growth conditions that are created by both tillage systems. Under the conditions of ploughless tillage, fruits and seeds of weeds, freshly shed every year, fall onto the soil surface, where they germinate and emerge under favourable conditions. In plough tillage, in turn, during tillage procedures they are moved from the field surface into the deeper soil layers and, at the same time, from the deeper layers onto the soil surface. In the present study, species of the upper layer made up a large group (22.9\%), that is, those which mature most frequently before the harvest of wheat and which thereby infest the soil, as well as weeds of the lower and ground layers $(37.1 \%)$ which mature and shed seeds in the stubble field, also increasing the soil diaspore bank. However, weeds of the middle layer made up the largest group (40\%); most of them mature at the same time as spring wheat and they infest primarily seed material as well as the soil.

\section{CONCLUSIONS}

1. The values of the measures of spring wheat weed infestation, i.e. number and air-dry weight of weeds per $1 \mathrm{~m}^{2}$ as well as weed species composition, varied in individual study years. Higher values of these parameters were found in the years with higher rainfall totals.

2. Compared to plough tillage, ploughless tillage significantly increased air-dry weight of weeds in the spring wheat crop. The tillage system under comparison did not differentiate the number of weeds per $1 \mathrm{~m}^{2}$.

3. Spring wheat sown using the plough tillage system was colonized most extensively by the following weed species: Avena fatua L., Stellaria media (L.) Vill., Galium aparine L., Amaranthus retroflexus L., Chenopodium album L., and Consolida regalis Gray. In the ploughless tillage treatments, the following weeds were predominant: Stellaria media (L.) Vill., Avena fatua L., Fallopia convolvulus (L.) A. Löve, Papaver rhoeas L., Amaranthus retroflexus L., Galium aparine L., and Chenopodium album L.

\section{REFERENCES}

Dzienia S., Dojss D., 1999. Wpływ systemów uprawy roli na zachwaszczenie i plonowanie pszenicy ozimej / Influence of systems of soil cultivation on weed infestation and yielding of winter wheat. Fol. Univ. Agric. Stetin., Agricultura, 195 (74): 185-190 (in Polish).

Feledyn-Szewczyk B., Duer I., 2007. Podobieństwo glebowego banku nasion i aktualnego zachwaszczenia łanu pszenicy ozimej w różnych systemach produkcji rolnej / Similarity between soil seed bank and current weed flora in winter wheat cultivated in different crop production systems. Ann. Univ. Mariae Curie Skłodowska, sect. E, 62 (2): 157-167 (in Polish).

Gawęda D., 2007. Zachwaszczenie pszenicy ozimej w warunkach zróżnicowanej uprawy roli / Winter wheat weed infestation under conditions of various tillage systems. Acta Agrophys., 10 (2): 317-325 (in Polish).

Kraska P., Pałys E., 2006. Zachwaszczenie łanu jęczmienia jarego w warunkach zróżnicowanych systemów uprawy roli oraz poziomów nawożenia i ochrony / Weed infestation in a canopy of spring barley in condition of different tillage systems and fertilization and plant protection levels. Acta Agrobot. 59, (2): 323-333 (in Polish).

Sekutowski T., Rola H., 2006. Wpływ systemów uprawy na bank nasion chwastów w glebie / Effect of tillage systems on seed bank in soil. Prog. Plant Protection / Post. Ochr. Roślin, 46 (2): 116-119 (in Polish).

Weber R., Hryńczuk B ., 2005. Wpływ sposobu uprawy roli i przedplonu na zachwaszczenie pszenicy ozimej / Influence of forecrop and mode of tillage on weed infestation of winter wheat. Ann. Univ. Mariae Curie Skłodowska, sect. E, 60: 93-102 (in Polish).

Wesołowski M., Woźniak A., 2001. Zachwaszczenie aktualne i potencjalne zbóż jarych w różnych systemach 
następstwa roślin / Present and potential weed infestation of spring cereals in different cropping systems. Acta Agrobot. 54 (1): 175-190 (in Polish).

Woźn ia k A., 2007. Zapas diaspor chwastów w glebie rędzinowej w stanowisku po pszenżycie jarym / Content of weed seeds in rendzina soil under spring triticale. Ann. Univ. Mariae Curie Skłodowska, sect. E, 62 (2): 250256 (in Polish).

Woźniak A., 2010. Zachwaszczenie pszenicy twardej w różnych systemach uprawy roli / Weed infestation of durum wheat in different tillage systems. Ann. Univ. Mariae Curie Skłodowska, sect. E, 65 (1): 56-63 (in Polish).

Wrzesińska E., Dzienia S., Wereszczaka J., 2003. Wpływ systemów uprawy roli na ilość i rozmieszczenie nasion chwastów w glebie / Effect of different cultivation systems on the number and composition of weed seeds in soil. Acta Sci. Pol., Agricultura, 2 (1): 169-175 (in Polish).

\section{Zachwaszczenie lanu} pszenicy jarej (Triticum aestivum L.) w warunkach płużnej i bezpłużnej uprawy roli

Streszczenie

Doświadczenie polowe prowadzono w latach 2007-2009 w Gospodarstwie Doświadczalnym Uhrusk (województwo lubelskie) należącym do Uniwersytetu Przyrodniczego w Lublinie. Czynnikami doświadczenia były zróżnicowane systemy uprawy roli - płużny i bezpłużny. W systemie płużnym uprawa roli polegała na wykonaniu po zbiorze przedplonu pielęgnowanej podorywki oraz orki przedzimowej. W systemie bezpłużnym zastosowano po zbiorze przedplonu jedynie herbicyd Roundup 360 SL (s.a. glifosat). Wiosenna uprawa roli $\mathrm{w}$ obu systemach polegała na kultywatorowaniu pola oraz zastosowaniu zestawu uprawowego złożonego z kultywatora, wału strunowego i brony. W doświadczeniu oceniono zachwaszczenie łanu wyrażone liczbą i powietrznie suchą masą chwastów oraz ich składem gatunkowym. Wykazano, że w warunkach bezpłużnej uprawy roli istotnie wzrosła powietrznie sucha masa chwastów w łanie pszenicy jarej, w stosunku do uprawy płużnej. Porównywane systemy uprawy roli nie różnicowały liczby chwastów na $1 \mathrm{~m}^{2}$. Pszenica jara wysiewana w warunkach płużnej uprawy roli najliczniej była zasiedlana przez: Avena fatua L., Stellaria media (L.) Vill., Galium aparine L., Amaranthus retroflexus L., Chenopodium album L. i Consolida regalis Gray. Na obiektach z bezpłużną uprawą roli przeważały: Stellaria media (L.) Vill., Avena fatua L., Fallopia convolvulus (L.) A. Löve, Papaver rhoeas L., Amaranthus retroflexus L., Galium aparine L. i Chenopodium album $\mathrm{L}$. 